\title{
ENERGY EFFICIENCY OF CULTURAL HERITAGE IN TOURISM DEVELOPMENT
}

\begin{abstract}
The energy efficiency of cultural heritage sites is an extremely important aspect of sustainable tourism development. The key feature lies in balancing the historical value of buildings, ensuring efficient energy consumption, meeting the needs of users and visitors, and ensuring their comfort. The implementation of energy efficiency measures in cultural heritage requires creative and advanced technological solutions, new tools, knowledge and training, change in the behavior of various buildings, adequate management of building, and a multidisciplinary approach to the problem. There is a need for cooperation between key stakeholders such as the owners of buildings, engineers, architects, conservators, local authorities and tourists. The aim of the paper is to prove that energy efficiency in cultural heritage is indeed pos-
\end{abstract}

\section{Introduction}

Because of the growing energy costs and the diminishing sources of fossil fuels, any type of energy saving is extremely important and leads to sustainable development. Increased demand for electrical energy dictates the need for a steady supply of electricity. The building sector is responsible for nearly $40 \%$ of the total energy consumption in Europe (Directive 2010/31/EU). Tourist destination management plans and tourism master plans (Morrison, 2013) can provide a sustainable framework for the protection of cultural heritage and the implementation of energy efficiency measures and improved energy management. They can also help to improve quality of life at tourist destinations and can be a powerful engine of economic and social development. Destination man- sible, as demonstrated by examples. Tourism destination management plans can provide a sustainable framework for the protection of cultural heritage and the implementation of energy efficiency measures. Furthermore, they can improve the quality of life in historical cores, thus representing a powerful tool for economic and tourist development. It can be concluded that there is no singular solution that could be applied to improve the energy efficiency of cultural heritage buildings. However, there are a number of sources of funding, new technologies and scientific tools that can be applied in order to contribute to the preservation of cultural heritage and sustainable tourism development.

Key words: energy efficiency, cultural heritage, sustainable development, tourism

agement is indicated as the wider structural unit, recognized in the academic literature as having the greatest priority in tourism or heritage planning and management (Manning, 2004; Swarbrooke, 1999). Energy improvement means to perform one or more interventions with the aim of reducing the energy performance index without changing the structural and architectural condition of the artifact, while trying to improve the quality of the environment (L.de Santoli, 2015, p. 537). Making cultural heritage buildings energy efficient does not necessarily have to be as complex and financially demanding as it may appear. Nevertheless, it is a fact that renovating buildings of cultural heritage does require considerable financial resources. The energy efficiency aspect should be taken into consideration as early as the preparation phase of any project for 
heritage building renovation. This paper presents some of the models of financing energy efficiency projects, including budget preparation, loans, ESCO models, etc. (Krstinić Nižić, Blažević, 2017, pp. 139-147).The energy renovation of cultural and monumental heritage is a challenging process that implies an interdisciplinary approach in all phases of a project, from the project idea to the implementation of investments. The research problem of this paper centers on identifying the specific features of the valorization of cultural heritage potential for tourism purposes to boost economic development. The paper aims to establish which elements influence the inclusion of cultural heritage in tourism flows, so that efficient cultural-heritage management may foster overall tourism development. The application of such a concept focuses heavily on meeting the needs of target markets and society at large. This specifically means that when introducing, exploiting and developing any product - including a tourism product - based on the use of cultural heritage assets, great care should be taken to preserve all the characteristics of the destination's environment, in terms of sociology, culture and ecology (Gredičak, 2011, p.2). Directly linked to the research problem is the primary purpose of the study: to establish and analyze, within the framework of economics, the contribution of energy renovation of cultural heritage buildings to energy savings as well as to tourism development. The aim is to explore the possibilities of valorizing cultural heritage for tourism development and underline the need of using tourism valorization of cultural heritage as a platform for the continuous generation of competitive advantages for a destination. The paper analyzes the energy renovation of a palatial building, selected from the project EE Culture, as an example of a comprehensive approach to the revitalization and energy renovation of protected buildings, thus taking into consideration structural, architectural and cul- tural-historical features of the building and its purpose. A review of the available academic literature shows many projects in the EU focused on improving energy efficiency in existing and historic buildings. Some of these projects are NEW4OLD, EFFESUS, 3ENCULT, RENERPATH, RESSEEPE, LIFE-INSU-SHELL, and PIME's (Vieites et al., 2015). Analyzing these projects, however, is not the aim of this paper. By delivering even the most minor project, not only does a tourist destination gain energy-renovated cultural heritage buildings in which working conditions are improved and the level of quality of services provided is higher, but the life cycle of the buildings is extended. Thus, the destination contributes directly to the reduction of power consumption in public-sector buildings and to the conservation of cultural heritage for future generations, which are priority objectives at the national level (https://ec.europa.eu). The purpose of this paper is to prove that the increase in the energy efficiency of cultural heritage buildings contributes to environmental protection as well as the conservation of cultural heritage at a tourist destination. The level of cultural heritage conservation reflects a society's level of development. Although architectural heritage has the potential of becoming one of the most important resources in developing cultural tourism in Croatia, as well as in other countries, there is no adequately developed and coordinated scientific, institutional and market-based system capable of valorizing architectural heritage according to the principles of sustainability. A number of studies identify heritage as one of the most significant and fastest growing components of tourism (Poria et al., 2003; Timothy, 2007). The contributions of this paper are two-fold. Firstly, it contributes to a better understanding of investments into energy efficiency in cultural heritage and, secondly, it puts forward specific financing solutions that refer to identifying, using and managing protected cultural heritage. 


\section{Analysis of the state of cultural heritage in the republic of Croatia}

Croatia is a country of rich cultural history. At present, in Croatia, 4930 cultural goods are under permanent protection, 564 are under preventive protection, and seven are under the special UNESCO protection (Strategy for the Protection, Conservation and Sustainable Economic Exploitation of the Cultural Heritage of the Republic of Croatia, UNESCO). Out of all monumental buildings in Croatia, 35\% are fully in a considerable state of disrepair (www.min-kulture.hr). Despite some cases of good maintenance and conservation of cultural goods, it can generally be said that Croatia's cultural goods are threatened by a number of factors, such as the abandonment and lack of upkeep of cultural heritage buildings, unresolved property relations, aging population and poverty, all of which result in dilapidation and disappearance of heritage. On the other hand, excessive urban expansion and new construction can also degrade and destroy cultural goods. The main reasons behind this lack of concern for heritage include a lack of awareness of its value; a lack of political will; low and inadequate investments; poor cooperation and coordination of action among sectors, such as urban development, tourism and the economy, that have a direct impact on cultural heritage; and the insufficient concern of institutions over heritage (Dumbović Bilušić, 2013, p. 6).

In Croatia, cultural goods fall within the competence of the Ministry of Culture. Conservation activities as well as the protection and preservation of cultural heritage are carried out by the Ministry's Directorate for the Protection of Cultural Heritage, which comprises a network of Conservation Departments, as well as the City Institute for the Protection of Cultural and Natural Monuments in Zagreb. The territorial distribution of the Conservation Departments of the Directorate for the Protection of Cultural Heritage matches Croatia's county structure. The City Institute for the Protection of Cultural and Natural Monuments in Zagreb is not part of the Ministry of Culture, but rather a part of the local and regional self-government. Because of its complexity, the monument heritage protection process comes within the competence of the Ministry of Culture as well as other national institutions such as the Ministry of Tourism and the Croatian National Tourist Board (Antolović and Škare, 2009). At the local and regional level, it is generally expected that this role should be taken up by local and regional tourist boards and county departments for culture and tourism (Jelinčić, 2008). Practice has shown, however, that despite the division of activities and tasks, problems exist with regard to uncoordinated and time-consuming administrative procedures, the capabilities of institutions (staff and competencies), the coordination of prescribed activities and tasks and, in particular, with regard to needed and available funds.

\section{Sources of funding energy renovation projects}

Energy renovation projects for the buildings of cultural heritage are challenging capital investments and their successful delivery largely depends on favorable sources of funding. Very high investments needed to increase energy efficiency and disproportional financial savings achieved are the reason why market-based financing models are not applicable to these types of projects. Most EU member states, including Croatia, have introduced financial assistance to ensure a higher level of investment profitability for investors. Financial assistance for conservation projects of cultural goods can be implemented from a variety of sources:

- National programs and donations from the budget (www.fzoeu.hr) - As a rule, funds from the state budget, earmarked for the protection and conservation of cultural goods, are allocated to the section of the budget set aside for the Ministry of Culture, which is 
responsible for the protection and conservation of cultural goods. Funds are granted through annual financial assistance programs based on the Strategic Plan of the Ministry of Culture. In addition to calls to apply for funding from the Environmental Protection and Energy Efficiency Fund, the Croatian Government has also launched a Program for the Energy Renovation of Family Houses (www.hr.undp.org) and public sector buildings, which enables building renovation based on a model for contracting ESCO energy-efficiency services (http://eesi2020.eu).

- Budgets of regional and local self-governments (counties, towns and municipalities) - Local and regional self-government units finance the renovation, maintenance and adaptation of cultural heritage through two main sources:

o Budgets of municipalities, towns and counties - Mostly only very small amounts are involved, with only Zagreb, Rijeka, Dubrovnik, Zadar and Split seeing substantial funds for renovation.

o Non-refundable funds from the monument annuity (www.zakon. hr) are earmarked for natural persons and legal entities and are granted upon the completion of a public call for tenders.

- European structural and investment funds (ESIF) - The ESIF is the primary source of most national programs for energy renovation and cultural heritage conservation, and the new financial framework has additionally strengthened its role. The 2014-2020 Competitiveness and Cohesion Operational Program enables the funding of activities such as the preparation of projects for the renovation of cultural heritage, the renovation and construction of auxiliary infrastructure, the improvement of cultural heritage management systems, and raising public awareness through education about and promotion of cultural heritage (https://ec.europa.eu/). This operational program places special emphasis on the renovation of cultural infrastructure to foster the development of tourism and other economic activities.

- Special EU programs - The EU has launched a large number of specialized programs, aimed at strengthening the capacities of stakeholders involved in initiating energy renovation projects (ELENA, JASPERS) and boosting promotional and research activities (Krstinić Nižić, Blažević 2009). European Territorial Cooperation programs (interregional, transnational and cross-border) foster international cooperation and the exchange of best practices to help strengthen and expand the integration of cross-border tourism offerings and improve the management of cultural and natural goods (Loulanski and Loulanski, 2011). These programs also fund demonstration and pilot projects for renovation in selected regions.

- Foundations- The purpose of many international and local foundations is to collect, manage and redistribute financial and other means beneficial to a community. The foundations operate for the specific period of time required to achieve goals for which they were established. This mode of project funding has become quite popular in recent years with the development of crowdfunding. Also, because of tax relief, corporate sponsorship is increasingly becoming a frequent way of ensuring direct or indirect heritage funding. 
Table 1. Activities Involved in the Energy Renovation of Cultural and Monument Heritage Buildings in Croatia

\begin{tabular}{|c|c|c|c|c|}
\hline & Activity & Description & Performed by & Notes \\
\hline 1. & $\begin{array}{l}\text { Submitting request } \\
\text { for expert opinion }\end{array}$ & $\begin{array}{l}\text { The investor submits } \\
\text { a request for expert } \\
\text { opinion regarding en- } \\
\text { ergy renovation needed } \\
\text { for a building. }\end{array}$ & Investor & $\begin{array}{l}\text { A request for expert opinion } \\
\text { does not necessarily have to be } \\
\text { submitted. The request should } \\
\text { describe the building and the } \\
\text { work planned. }\end{array}$ \\
\hline 2. & $\begin{array}{l}\text { Providing conserva- } \\
\text { tory guidelines }\end{array}$ & $\begin{array}{l}\text { The competent con- } \\
\text { servation department } \\
\text { provides conservatory } \\
\text { guidelines on energy } \\
\text { renovation works, to } \\
\text { serve as design guide- } \\
\text { lines. }\end{array}$ & $\begin{array}{c}\text { Conservation } \\
\text { department }\end{array}$ & - \\
\hline 3. & $\begin{array}{l}\text { Selecting a lead } \\
\text { designer }\end{array}$ & $\begin{array}{l}\text { The investor selects a } \\
\text { lead designer, which } \\
\text { has approval for con- } \\
\text { ducting works on the } \\
\text { protection and con- } \\
\text { servation of cultural } \\
\text { goods, for elaborating } \\
\text { a conceptual design, } \\
\text { master design and } \\
\text { execution design. }\end{array}$ & Investor & $\begin{array}{l}\text { The website of the Ministry of } \\
\text { Culture provides a list of nat- } \\
\text { ural persons and legal entities } \\
\text { with the approval to carry out } \\
\text { works on the protection and } \\
\text { conservation of cultural goods. }\end{array}$ \\
\hline 4. & Designing & $\begin{array}{l}\text { The lead designer elab- } \\
\text { orates a master design } \\
\text { to improve a building's } \\
\text { energy efficiency de- } \\
\text { pending on the extent } \\
\text { of renovation (civil, } \\
\text { mechanical and/or } \\
\text { electrical engineering } \\
\text { measures). }\end{array}$ & Lead designer & - \\
\hline 5. & $\begin{array}{l}\text { Cooperation in } \\
\text { the master design } \\
\text { phases }\end{array}$ & $\begin{array}{l}\text { In the design phase, the } \\
\text { lead designer should } \\
\text { closely cooperate with } \\
\text { the competent conser- } \\
\text { vation department and } \\
\text { submit documents for } \\
\text { consideration as to the } \\
\text { various phases of the } \\
\text { master design (details, } \\
\text { materials selected, etc.) } \\
\text { to facilitate and expe- } \\
\text { dite the procurement } \\
\text { of prior approval of the } \\
\text { master design. }\end{array}$ & $\begin{array}{l}\text { Conservation } \\
\text { department/ } \\
\text { lead designer }\end{array}$ & $\begin{array}{l}\text { In this phase, corrections are } \\
\text { made to solutions selected, } \\
\text { materials used, design details, } \\
\text { etc. to shorten the time needed } \\
\text { to obtain prior approval of the } \\
\text { master design. }\end{array}$ \\
\hline
\end{tabular}




\begin{tabular}{|c|c|c|c|c|}
\hline & Activity & Description & Performed by & Notes \\
\hline 6. & $\begin{array}{l}\text { Request for prior } \\
\text { approval of the mas- } \\
\text { ter design }\end{array}$ & $\begin{array}{l}\text { The investor submits } \\
\text { a request to the con- } \\
\text { servation department } \\
\text { for prior approval } \\
\text { of the master design } \\
\text { for improving the } \\
\text { energy efficiency of } \\
\text { the building envelope. } \\
\text { Two copies of the } \\
\text { master design should } \\
\text { be attached to the prior } \\
\text { approval request. }\end{array}$ & $\begin{array}{l}\text { Investor/ } \\
\text { conservation } \\
\text { department }\end{array}$ & $\begin{array}{l}\text { The prior approval to the mas- } \\
\text { ter design lays out the condi- } \\
\text { tions that must be adhered to } \\
\text { during execution of work and } \\
\text { states that all the works carried } \\
\text { out will be supervised by the } \\
\text { conservation department. }\end{array}$ \\
\hline 7. & $\begin{array}{l}\text { Selecting the main } \\
\text { contractor }\end{array}$ & $\begin{array}{l}\text { The investor selects } \\
\text { a main contractor, } \\
\text { which has approval } \\
\text { for execution of works } \\
\text { on the protection and } \\
\text { conservation of cul- } \\
\text { tural goods as well as } \\
\text { to carry out works on } \\
\text { the immovable cultural } \\
\text { good. }\end{array}$ & Investor & $\begin{array}{l}\text { The website of the Ministry } \\
\text { of Culture provides a list of } \\
\text { natural persons and legal enti- } \\
\text { ties with approval to carry out } \\
\text { works on the protection and } \\
\text { conservation of immovable } \\
\text { cultural goods, with regard to } \\
\text { the type of works involved and } \\
\text { the duration. }\end{array}$ \\
\hline 8. & $\begin{array}{l}\text { Selection of expert } \\
\text { and design super- } \\
\text { vision }\end{array}$ & $\begin{array}{l}\text { The investor selects } \\
\text { expert and design } \\
\text { supervision to monitor } \\
\text { works carried out on } \\
\text { the immovable cultural } \\
\text { good. Expert super- } \\
\text { vision is conducted } \\
\text { by persons author- } \\
\text { ized pursuant to the } \\
\text { Construction Act (Offi- } \\
\text { cial Gazette } 153 / 13) \text {. } \\
\text { Design supervision is } \\
\text { conducted according } \\
\text { to the Act on architec- } \\
\text { tural and engineering } \\
\text { tasks and activities } \\
\text { in physical planning } \\
\text { and building }(O f f i c i a l \\
\text { Gazette } 152 / 08,124 / 09 \text {, } \\
\text { 49/11, 25/13). }\end{array}$ & Investor & $\begin{array}{l}\text { Design supervision is selected } \\
\text { as required or if stipulated in } \\
\text { the master design. }\end{array}$ \\
\hline 9. & $\begin{array}{l}\text { Conservation su- } \\
\text { pervision }\end{array}$ & $\begin{array}{l}\text { The conservation } \\
\text { department conducts } \\
\text { conservation super- } \\
\text { vision of the works } \\
\text { carried out based on } \\
\text { the prior approval of } \\
\text { the master design. }\end{array}$ & $\begin{array}{c}\text { Conservation } \\
\text { department }\end{array}$ & $\begin{array}{l}\text { Either the investor or the } \\
\text { investor's assignee reports } \\
\text { the beginning of work on the } \\
\text { immovable cultural good to } \\
\text { the competent conservation } \\
\text { department. }\end{array}$ \\
\hline
\end{tabular}




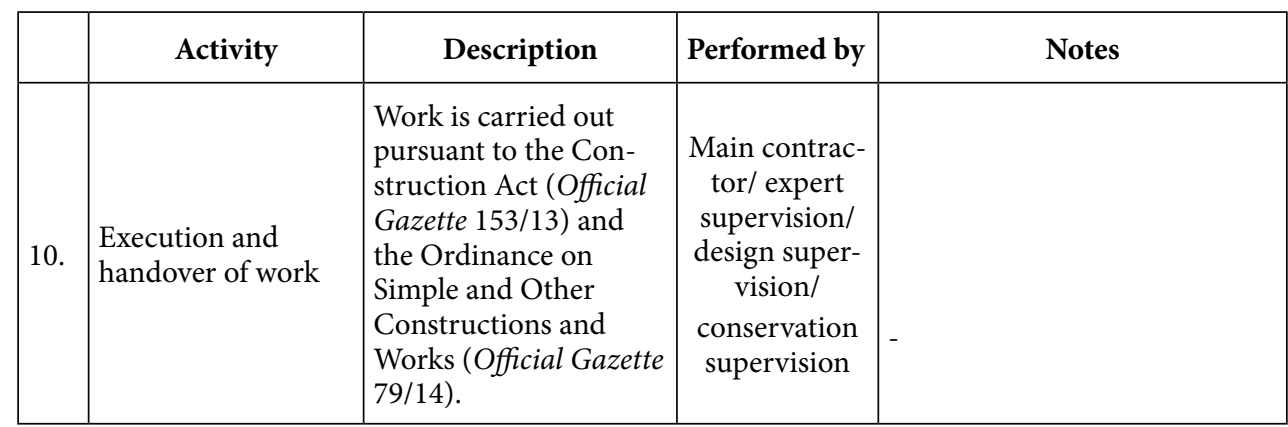

Source: Energy Efficiency in Cultural Heritage (2015), EE Culture, North-West Croatia Regional Energy Agency, Zagreb, p.26.

The law recognizes cultural heritage as one of the categories of public goods. All issues and relationships pertaining to private and public interests in maintaining and planning cultural heritage call for cooperation among, and consideration of, all stakeholders: building owners, users, experts (conservators, civil engineers), public administration and the general public.

Public participation facilitates the implementation of energy renovation and all other activities involved in the process. The involvement of the public in decision-making often requires the elaboration of more accurate and in-depth analysis and design documents. Such analyses can reveal inefficiencies in current or planned practice, but they can also highlight the advantages of using new technologies and materials in energy renovation. Educating citizens, as well as experts, is essential in encouraging public participation.

To educate the public regarding energy renovation, target groups should be identified. These target groups can be structured in a variety of ways. Target groups according to the mode of participation in projects for the energy renovation of cultural heritages are the following:

- the entire population

- building owners

- the Croatian Government and state administration bodies

- local and regional government and self-government

- bankers and potential investors

- construction companies and entrepreneurs

- scholars and experts

- public communication media

- public opinion influencers

- NGOs

- political parties

- the international community.

Key activities in delivering projects for the energy renovation of cultural heritage involve ensuring information visibility and the participation of relevant stakeholders. Project stakeholders are members of the general and professional public who are affected by the project decisions or those who can influence the implementation of project decisions. Through accurate identification and involvement of relevant stakeholders in project activities, the project team will be able to align project outcomes and objectives with the needs and expectations of society, which will, ultimately, contribute to the sustainability of the project. Generally speaking, stakeholders taking part in a project either have the role of information provider or the role of information recipient.

The following example of a county palatial building in Krapina in Croatia demonstrates that energy savings as high as $28.9 \%$ could be gained through energy renovation using the measures presented. 
Table 2. Energy Renovation in the Case of a County Palatial Building in Krapina, Croatia

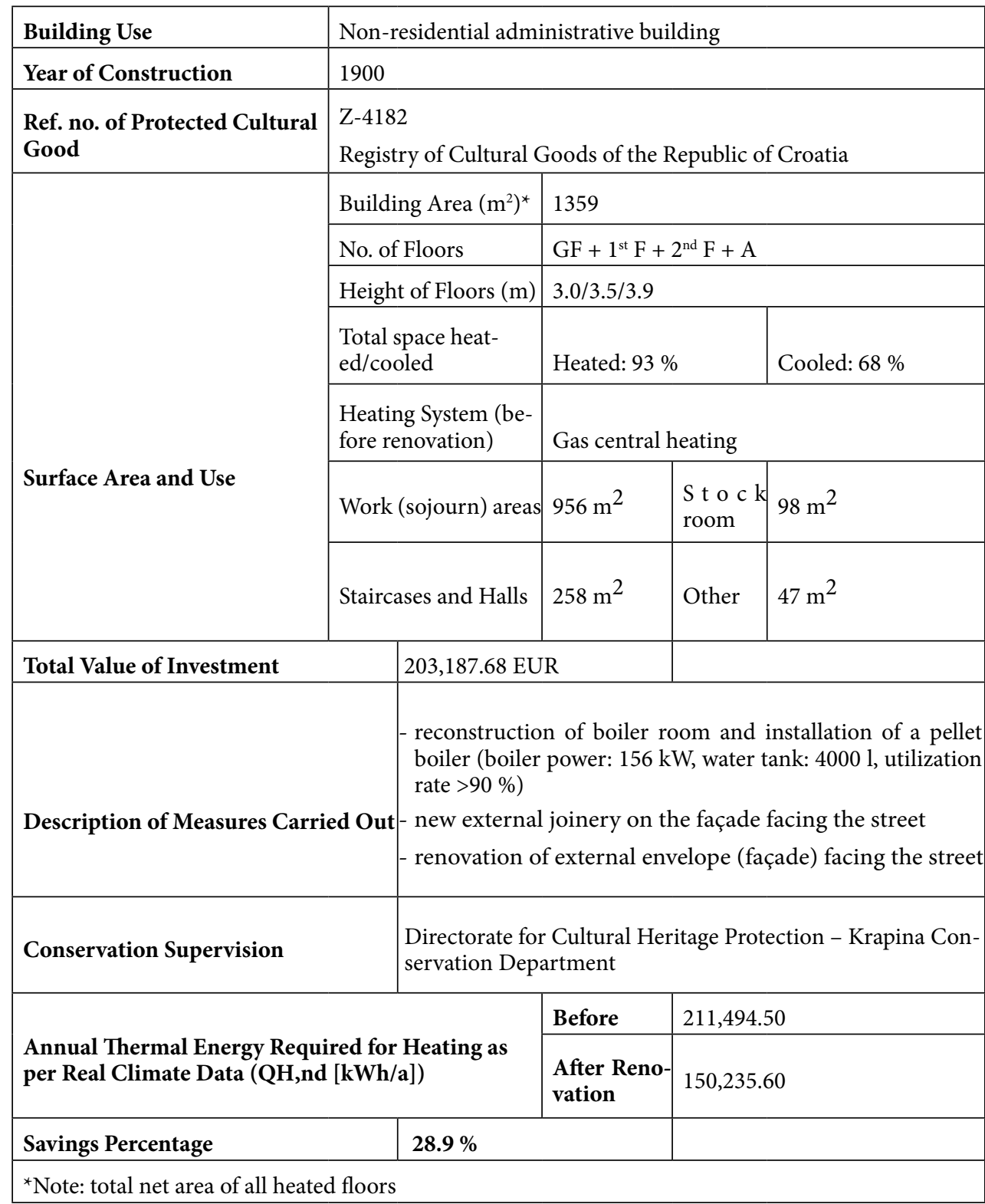

Source: Energy Efficiency in Cultural Heritage (2015), EE Culture, North-West Croatia Regional Energy Agency, Zagreb, p.34. 
A consensus is required to define objectives of a plan for introducing energy efficiency measures, thus workshops and the media should be used to raise awareness and broaden the knowledge of local communities about the importance of the sustainable planning and renovation of protected cultural heritage buildings. Only, in this way, will stakeholders in the sustainable use of energy projects be able to benefit from the energy renovation of protected cultural goods and foster sustainable tourism development.

\section{Conclusion and recommendations}

The energy renovation of buildings of cultural and monument heritage is a challenging process that implies an interdisciplinary approach to all project phases, from the project idea to the implementation of investments. It is necessary to raise awareness of the importance of safe-guarding historical and cultural heritage from decline and destruction, thus safeguarding national identity. Key participants in spatial management and investment planning need to connect with the professional and scientific community and citizens, because the way people relate to heritage largely depends upon their ability to identify and valorize edifices of cultural heritage. Energy renovation projects for cultural heritage target project partners, municipalities, towns and their inhabitants, workers, and users of reconstructed facilities, as well as the professional and general public.

Activities involved in energy renovation must take into consideration the specific features of buildings and their use, in terms of civil engineering, architecture, culture and history.

Based on the analysis carried out here, the following guidelines can be recommended (www.regea.org/eeculture/):

- A digital database of guidelines for energy renovation should be made available to the public. The database should contain information about the types of materials allowed, installation details, solutions for thermal bridges, etc. according to the typology and period of construction. This would facilitate and expedite the elaboration of design documents and the issuance of prior approval of the master design.

- It is essential to involve all relevant stakeholders and experts of various professions from the very beginning of any project for the energy renovation of monument heritage.

- A thorough risk analysis (property-rights relations, the occurrence of other works required prior to energy renovation, possible energy savings, project guidelines of the competent conservation department, etc.) should be conducted.

- The design process should include cost optimization and should explore the possibility of using renewable energy sources as well as novel insulation materials (mortar, insulation, remedial treatment for rising damp by capillary action, statics, etc.)

- Best-practice examples should be communicated, and knowledge and experience, exchanged.

The example of the renovation of a protected building in Krapina, as part of the project EE Culture, proves that it is possible to combine energy renovation and building conservation through the use of new materials and technologies to reduce energy consumption and save a building from decay.

The delivery of such a project helps to overcome obstacles, which may often emerge as a consequence of a lack of needed information and data as well as in-depth studies and organizational knowledge with the arise of conflicts in defining different priorities and values and, by doing so, the project facilitates sustainable cultural heritage management. In such projects, the bulk of the investment is returned through savings and they have the additional advantages of helping to increase the quality of life, making stays at a tourist destination more comfortable with the ex- 
tension of tourist season. It is necessary for all stakeholders to actively participate in the energy renovation of protected cultural monuments, keeping abreast of EU standards for the conservation of architectural heritage for the present and future generations. It is also vital that civil engineers, architects, conservators and building owners are aware of the major issues and obstacles mentioned above and that they are willing to actively search for new technological solutions in building renovation.

Facts above stated lead to the conclusion that an imperative issue of our times is renovation, protection and presentation of cultural heritage. Encouraging scientific studies is exceptionally important in that context. Based on such studies, the state should educate the population and raise awareness of the value of natural and cultural heritage. The harmony and interdependency of nature and culture as well as the deeply rooted historical architectural traditions and landscape architecture of any country, as a tourist destination, can make it ideal for interdisciplinary study, research and popularization of its entire national, natural and cultural heritage with the aim of fostering tourism development and, in turn, overall economic development. Long-term tourism development in Croatia needs to be grounded on the active protection of its cultural and historical heritage as well as its natural heritage. Croatia has the real, though, poorly researched potential for exploiting and developing cultural heritage-based services and facilities to boost tourism development. In addition, cultural heritage energy efficiency projects help to strengthen the cultural identity of a region, reduce the emission of greenhouse gases, and promote integrated regional tourism development.

\section{Acknowledgements}

This paper has been financially supported by the University of Rijeka, for the project ZP UNIRI 4/16.

\section{References}

Antolović, J., Škare, M. (2009) Monument annuity as economic instrument - from theory to Croatian practice, Economic research - Ekonomska istraživanja, Vol.19 No2, 91-106.

Četvrti nacionalni akcijski plan energetske učinkovitosti za razdoblje od 2017 - 2019, (2017) Ministarstvo zaštite okoliša i energetike, https://ec.europa.eu/ energy/sites/ener/files/documents/ hr_neeap_2017_hr.pdf(Accessed 201802-12)

Directive 2010/31/EU on the Energy Performance of buildings. http://eur-lex. europa.eu/legalcontent/EN/TXT/PD$\mathrm{F} /$ ?uri=CELEX:32010L0031\&from $=\mathrm{EN}$

Dumbović Bilušić, B. (2013) Kulturna baština u Hrvatskoj pred novim izazovima, Kvartal X-1/2, 6-11.

Europski strukturni i investicijski fondovi (ES1F)

https://ec.europa.eu/info/funding-tenders-0/european-structural-and-investment-funds_hr (Accessed 2018-01-15)

Effesus http://www.effesus.eu/ (Accessed 2018-01-12)

3encult http://www.3encult.eu/en/project/ welcome/default.html (Accessed 201801-12)

European Energy Service Initiative 2020 http://eesi2020.eu/(Accessed 2018-0123)

Energetska učinkovitost u kulturnoj baštini (2015), EE Culture, Regionalna energetska agencija Sjeverozapadne Hrvatske, Zagreb www.regea.org/eeculture/(Accessed 2018-01-15)

Fond za zaštitu okoliša i energetsku učinkovitost www.fzoeu.hr (Accessed 2018-0115)

Gredičak, T. (2011) Upravljanje lokalnim ekonomskim razvojem - turistička valorizacija kulturne baštine u funkciji ekonomskog razvoja, međunarodni znanstveno-stručni skup Modeli upravljanja procesima obnove i razvoja povijesnih 
gradova Primjer Ivanić-Grada: Mogućnosti revitalizacije i obnove starog Ivanića, Ivanić-Grad, 1-11.

House in Order" (HiO Programme) http:// www.hr.undp.org/content/croatia/en/ home/operations/projects/environment_and_energy/RemovingBarriers. html(Accessed 2018-02-12)

Jelinčić, D. (2008) Abeceda kulturnog turizma, Zagreb, Meandarmedia.

Krstinić Nižić, M., Blažević, O. (2009) Europska podrška ulaganjima u obnovu $i$ održivi razvitak malih povijesnih grado$v a, 2$. međunarodna konferencija Revitalizacija malih povijesnih gradova $i$ njihovog okruženja u Primorsko-goranskoj županiji, Mošćenice, 23.- 24.10. 2009., 232-252.

Krstinić Nižić, M., Blažević, B. (2017) Gospodarenje energijom $u$ turizmu, Fakultet za menadžment u turizmu iugostiteljstvu, Opatija.

Life-insu-shell. http://ec.europa.eu/environment/life/project/Projects/index. $\mathrm{cfm}$ ? fuseaction =search.dspPage\&n proj_id=3084\&docType $=$ pdf (Accessed 2018-01-12)

Loulanski, T., Loulanski, V. (2011). The sustainable integration of cultural heritage and tourism: a meta-study, Journal of Sustainable Tourism, 19:7, 837-862.

L. de Santoli (2015) Guidelines on energy efficiency of cultural heritage, Energy and Buildings,

Vol.86, 534-540.

Manning, E. (2004). Indicators of sustainable development for tourism destinations. Retrieved July 20, 2010, from http://www.tourisk.org(Accessed 201801-05)

Morrison, A. M. (2013) Marketing and managing tourism destination, Routledge, Tailor and Francis.

New4old. http://www.new4old.eu/ (Accessed 2018-01-13)

Pime's. http://www.pimes.eu/ (Accessed 2018-01-13)
Poria, Y., Butler, R., \& Airey, D. (2003) The core of heritage tourism. Annals of Tourism Research, 30(1), 238-254.

Pravilnik o jednostavnim i drugim građevinama i radovima ( $\mathrm{NN}$ br. $79 / 14)$

Project 3encult. http://www.3encult.eu/en/ deliverables/Documents/2011_EM_ Troi_Impact.pdf (Accessed 2018-01-12).

Renerpath. www.renerpath.eu (Accessed 2018-01-13)

Resseepe. http://www.resseepe-project.eu/ (Accessed 2018-01-12)

Resseepe deliverables. http://www.resseepe-project.eu/documents/PUdeliverables/D3.2-strategies-thermal-energystorage.pdf (Accessed 2018-01-12)

Strategija zaštite, očuvanja i održivog gospodarskog korištenja kulturne baštine Republike Hrvatske za razdoblje 2011. $-2015$.

http://www.min-kulture.hr/userdocsimages/bastina/STRATEGIJA_BASTINE_ VRH.pdf(Accessed 2018-01-10)

Swarbrooke, J. (1999). Sustainable tourism management. Wallingford, UK: CABI Publishing.

Timothy, D. (Ed.). (2007). Managing heritage and cultural tourism resources. Aldershot: Ashgate.

UNESCO. (2004). Pilot project: Cultural heritage management and tourism - Models for cooperation among stakeholders. Final report prepared in cooperation with the Nordic World HeritageFoundation, Oslo. Retrieved February 12, 2011, from http://www.unescobkk.org/fileadmin/ userupload/culture/AAHM/Resources/CHMangmtTourism.pdf (Accessed 2018-02-01)

Vieitesa, E., Vassilevab, I., Ariasa, E.J. (2015) European initiatives towards improving the energy efficiency in existing and historic buildings, The 7th International Conference on Applied Energy - ICAE2015, Energy Procedia 75, 1679 $-1685$. 
Zakon o zaštiti i očuvanju kulturnih dobara (NN 69/99, NN 151/03; NN 157/03 Ispravak, NN 87/09,NN 88/10, NN 61/11, NN 25/12, NN $136 / 12$, NN 157/13,NN 152/14 i 44/17)https://www.zakon.hr/z/340/ Zakon-o-za\%C5\%A1titi-i-o\%C4\%8Duvanju-kulturnih-dobara(Accessed 2018-01-10)
Zakon o gradnji (NN br. 153/13)

Zakon o arhitektonskim i inženjerskim poslovima i djelatnostima $\mathrm{u}$ prostornom uređenju i gradnji (NN br. 152/08, 124/09, 49/11, 25/13) 